To cite this article: Chardes Marihot Tampubolon, Sovian Aritonang and Rohman Saleh Arto (2021). OPTIMIZATION OF HULL PROTECTIVE MATERIALS USING SACRIFICIAL ANODES: REVIEW, International Journal of Education and Social Science Research (IJESSR) 4 (6): 295-311

\title{
OPTIMIZATION OF HULL PROTECTIVE MATERIALS USING SACRIFICIAL ANODES: REVIEW
}

\author{
Chardes Marihot Tampubolon', Sovian Aritonang² and Rohman Saleh Arto ${ }^{3}$ \\ ${ }^{1}$ Graduate School, Faculty of Defense Strategy, Indonesia Defense University, \\ Jl. Sentul - Citeureup, Sentul, Kec. Citeureup, Bogor, Jawa Barat 16810, Indonesia \\ ${ }^{2}$ Program in Motion Technology Studies, Faculty of Defense Technology, Indonesia Defense University \\ J1. Sentul - Citeureup, Sentul, Kec. Citeureup, Bogor, Jawa Barat 16810, Indonesia \\ ${ }^{3}$ Graduate School, Faculty of Defense Strategy, Indonesia Defense University, \\ J1. Sentul - Citeureup, Sentul, Kec. Citeureup, Bogor, Jawa Barat 16810, Indonesia
}

DOI: http://dx.doi.org/10.37500/IJESSR.2021.4622

\begin{abstract}
The use of steel as a ship's hull has become a necessity in maritime technology. Protection of the hull against corrosion in the marine environment is very important. Many methods have been carried out in the context of such protection, one of which is the use of a sacrificial anode which works based on the principle of cathodic protection. Cathodic protection is the protection of the surface of the hull, especially below the waterline, by using a sacrificial anode, which is a metal that has a lower potential such as aluminum or zinc. The use of cathodic protection is influenced by the speed of the ship where the speed of the ship affects the formation of the layer which has an effect on the design of cathodic protection. so that in optimizing the hull protection material, the selection of sacrificial anodes must pay attention to density, protection potential, thrust stress, capacity and efficiency produced then the most important thing is the selection of materials were based on several studies aluminum has the best ability as a sacrificial anode. The position of the sacrificial anode is also important to note because it affects the corrosion rate of the sacrificial anode.
\end{abstract}

KEYWORDS: Cathodic Protection, Corrosion, Sacrificial Anode, Steel

\section{INTRODUCTION}

Ship is a means of sea transportation that has dynamic technological developments. The development of ship hull technology is currently quite rapid, namely the use of steel as the hull. However, the sea water environment is very influential on the resistance of steel because of the corrosive nature of sea water. The marine environment is widely used by industries, such as shipping, offshore oil and gas production, power generation, and coastal industrial manufacturing. Corrosion is a process that damages a material because it reacts with its environment [1]. The problem of corrosion in the marine 
environment has been studied for a long time, so there is quite a lot of information, but corrosion of materials in the marine environment still occurs [2].

The ship's operating environment is very corrosive, because seawater has a high salt content and contributes greatly to the rust formation reaction. Protection of the ship's hull against corrosion is very important, where it can extend the operating time of the ship which will automatically provide economic value for ship owners. In addition, the protection of the hull will provide a guarantee of safety for the crew, because the condition of the hull is protected from leakage due to corrosion. The seawater environment, with concentrations of $\mathrm{NaCl}$ or other types of salts will cause the metal corrosion rate to be fast [3]. Corrosion is the event of the release of electrons from metals (iron or steel) in an electrolyte solution such as sea water [4]. To avoid this rust, it is necessary to have a ship hull protection system made of steel.

Corrosion control can be achieved by recognizing and understanding corrosion mechanisms, namely by using corrosion-resistant materials and designs, using protective systems and treating corrosion. Many methods have been carried out for this protection, one of which is the use of a sacrificial anode which works based on the principle of cathodic protection [3]. Cathodic protection is the protection of the surface of the hull especially below the waterline by using a sacrificial anode, which is a metal that has a lower potential such as aluminum or zinc. The sacrificial anode protects the metal that has a higher potential which becomes the cathode, namely the metal that is the hull of the ship. The cathodic protection method with a sacrificial anode has a simple design and easy installation.

\section{RESEARCH METHOD}

In this study the authors used a qualitative approach. Sugiyono stated that, qualitative research methods are research methods based on the philosophy of post positivism, used to examine the conditions of natural objects, (as opposed to experiments) where the researcher is the key instrument, the data collection technique is done by triangulation (combined), data analysis. are inductive / qualitative, and the results of qualitative research emphasize meaning rather than generalization [5].

Meanwhile, according to Hardani, qualitative research is a study that basically uses a deductiveinductive approach. This approach departs from a theoretical framework, the ideas of experts, as well as the understanding of researchers based on their experiences which are then developed into problems and their solutions that are proposed to obtain justification (verification) in the form of support for empirical data in the report [6].

The research method is basically a scientific way of obtaining data for specific purposes and uses. Based on this, there are four key words that need to be considered, namely, scientific method, data, objectives, and usability [5]. Meanwhile, according to Kurniawan and Puspitaningtyas, the research method is a scientific method or technique to obtain data for specific purposes and uses [7]. 
Vol. 4, Issue.6, Nov-Dec 2021, p no. 295-311

\section{Data Collection and Analysis}

The data collection techniques that the authors use in this study are tailored to the focus and objectives of the study, namely:

The librarian study contains a systematic study of literature and the results of previous research that are related to the research that will be carried out and endeavored to show the current state of the field of science "the state of the art", a literature study conducted before conducting the research [8].

Meanwhile, according to Sugiyono, library research is a theoretical study, references and other scientific literature related to culture, values and norms that develop in the social situation under study [9].

Documents are records of events that have already occurred / have occurred. Documents can be in the form of writings, pictures, or the landmark works of others. Documents in the form of writing, for example diaries, life histories, stories, biographies, regulations, policies, and others. Documents in the form of images, such as photos, live pictures, sketches, films, videos, CDs, DVDs, and others. Documents in the form of works include works of art, paintings, sculptures, manuscripts, writings, inscriptions and so on.

Interpretive means that a document is a written or printed record of past events, it can be in the form of anecdotal notes, letters, diaries and documents. Office documents include internal sheets, communications to various publics, student and employee files, program descriptions and teaching statistics. Nasution explained that: "There are non-human resources, including documents, photos and statistical materials [10].

\section{RESULT AND DISCUSSION}

\subsection{Corrosion}

The cause of metal decay is a natural consequence of the presence of metal in the environment. The formation of metals from mineral forms occurs naturally and requires energy [11]. The reaction of the metal with its environment will make the metal return to its original state. In the conversion of iron ore into metal requires energy so that potential energy is stored in the metal, and the process of returning metallic iron to the original compound also requires energy, this process is called corrosion. The table below shows specimens in a seawater environment where the metal returns to its natural mineral form during the corrosion process [11]. 
Vol. 4, Issue.6, Nov-Dec 2021, p no. 295-311

Table. 1. Results of X-Ray Diffraction of Specimens Found in the Marine Environment [11]

\begin{tabular}{|c|c|c|}
\hline Sample Description & Chemical or Mineral Name & Chemical Formula \\
\hline \multirow{12}{*}{$\begin{array}{l}\text { Product of Unit conversion in marine } \\
\text { environment }\end{array}$} & Zinc ferrite & $\mathrm{ZnOFe}_{2} \mathrm{O}_{3}$ \\
\hline & Cobalt ferrite & $\mathrm{CoO} \mathrm{Fe}_{2} \mathrm{O}_{3}$ \\
\hline & Cobaltous ferrite & $\mathrm{CoO} \mathrm{Fe}{ }_{2} \mathrm{O}_{3}$ \\
\hline & Halite & $\mathrm{NaCl}$ \\
\hline & Chromic oxide & $\mathrm{Cr}_{2} \mathrm{O}_{3}$ \\
\hline & Nickel, zinc ferrospinel & $(\mathrm{Ni}, \mathrm{Zn}) \mathrm{O} \mathrm{Fe}_{2} \mathrm{O}_{3}$ \\
\hline & Sodium fluorate & $\mathrm{Na}_{3} \mathrm{Th}_{2} \mathrm{~F}_{11}$ \\
\hline & Embolites & $\mathrm{Ag}(\mathrm{Cl}, \mathrm{Br})$ \\
\hline & Magnesioferrite & $\mathrm{MgFe}_{2} \mathrm{O}_{4}$ \\
\hline & Beryllium palladium & $\mathrm{BePd}$ \\
\hline & Magnetite & $\mathrm{Fe}_{3} \mathrm{O}_{4}$ \\
\hline & Nickel titanium & $\mathrm{NiTi}$ \\
\hline \multirow[t]{5}{*}{$\begin{array}{l}\text { Products of } \mathrm{Al}-\mathrm{Cu} \text { alloy Exposed to } \\
\text { Marine environment }\end{array}$} & $\begin{array}{l}\text { Ammonium copper fluoride } \\
\text { dihydrate }\end{array}$ & $(\mathrm{NH} 4) 2 \mathrm{CuF} 42 \mathrm{H} 2 \mathrm{O}$ \\
\hline & Potassium cyanide & $\mathrm{KCN}$ \\
\hline & Chi alumina & $\mathrm{Al} 2 \mathrm{O} 3$ \\
\hline & Calcium aluminate & $3 \mathrm{CaO} \cdot \mathrm{A} 12 \mathrm{O} 3$ \\
\hline & Alpha cadmium iodide & $\mathrm{CdI} 2$ \\
\hline \multirow{2}{*}{$\begin{array}{l}\text { Products of } \mathrm{Al}-\mathrm{Zn}-\mathrm{Mg}-\mathrm{Cu} \text { alloy exposed } \\
\text { to Marine environment }\end{array}$} & Chi alumina & $\mathrm{Al} 2 \mathrm{O} 3$ \\
\hline & Alpha cadmium iodide & $\mathrm{CdI} 2$ \\
\hline \multirow{3}{*}{$\begin{array}{l}\text { Products of Al-Mn alloy exposed to } \\
\text { Marine environment }\end{array}$} & Ammonium copper fluoride & $(\mathrm{NH} 4) 2 \mathrm{CuF} 4 \cdot 2 \mathrm{H} 2 \mathrm{O}$ \\
\hline & dihydrate & $\mathrm{CaB} 6 \mathrm{O} 10 \cdot 4 \mathrm{H} 2 \mathrm{O}$ \\
\hline & Nobleite & \\
\hline
\end{tabular}


Table 1 above is the result of X-ray diffraction where the products found are specimens exposed to the marine environment. It is seen that the metal will return to its mineral form naturally during the corrosion process. The variation of energy required for metals during the corrosion process such as magnesium, aluminum and iron is relatively high, while for copper, silver and gold metals are relatively low. Table 2 shows the level of energy required during the oxidation process.

Table. 2. Position of Metals in Energy Sequence in order of conversion Oxides to Produce 1 Kilogram of Metal

\begin{tabular}{clll}
\hline & Metal & Oxide & Energy (MJ kg-1) \\
\hline Highest & $\mathrm{Li}$ & $\mathrm{Li}_{2} \mathrm{O}$ & 40.94 \\
Energy & $\mathrm{Al}$ & $\mathrm{Al}_{2} \mathrm{O}_{3}$ & 29.44 \\
& $\mathrm{Mg}$ & $\mathrm{MgO}$ & 23.52 \\
& $\mathrm{Ti}$ & $\mathrm{TiO}_{2}$ & 18.66 \\
& $\mathrm{Cr}$ & $\mathrm{Cr}_{2} \mathrm{O}_{3}$ & 10.24 \\
& $\mathrm{Na}$ & $\mathrm{Na} 2 \mathrm{O}$ & 8.32 \\
& $\mathrm{Fe}$ & $\mathrm{Fe} 2 \mathrm{O} 3$ & 6.71 \\
& $\mathrm{Zn}$ & $\mathrm{ZnO}$ & 4.93 \\
& $\mathrm{~K}$ & $\mathrm{~K} 2 \mathrm{O}$ & 4.17 \\
& $\mathrm{Ni}$ & $\mathrm{NiO}$ & 3.65 \\
& $\mathrm{Cu}$ & $\mathrm{Cu} 2 \mathrm{O}$ & 1.18 \\
& $\mathrm{~Pb}$ & $\mathrm{PbO}$ & 0.92 \\
& $\mathrm{Pt}$ & $\mathrm{PtO} 2$ & 0.44 \\
Enowest & $\mathrm{Ag}$ & $\mathrm{Ag} 2 \mathrm{O}$ & 0.06 \\
\hline Energy & $\mathrm{Au}$ & $\mathrm{Au} 2 \mathrm{O} 3$ & -0.18 \\
\hline
\end{tabular}

Source. Pierre R. Roberge, Ph.D., P.Eng. (2008)

In table 2, the reactivity of magnesium and aluminum which have high energy during the process of change is parallel to the metal. Metals are stable ores of oxides such as carbonates or sulfides [12]. In converting metals into materials that can be utilized, energy is needed. Then, corrosion is a reverse process that converts metal into its original element. because naturally the metal will return to a more stable thermodynamic condition as a compound [13]. One of the key factors in the corrosion process is the environment. Thus, theoretically the activity of a particular metal or alloy can be evaluated by knowing the chemical variations in the environment. Therefore, it is important to adjust the metal to changes in its environment both in time and in conditions because it greatly affects the condition of the metal according to the microenvironmental [2]. Pierre RR (1999) gives a simple description of the electrochemical properties of the corrosion process as shown below. 


\section{International Journal of Education and Social Science Research}

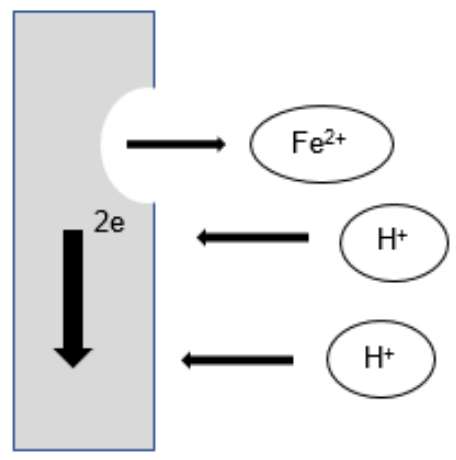

Figure 1. A simple model of the electrochemical properties of the corrosion process.

Cathodic reactions are generally much slower than the above model for cathodic reactions:

$$
2 \mathrm{H}++2 \mathrm{e}-\rightarrow \mathrm{H} 2
$$

This reaction proceeds rapidly under acidic conditions, but slows down under alkaline conditions. For pure iron, $\mathrm{H} 2$ on a metal surface will change gradually, because of the reaction of iron with the acid continues over time. The cathodic reaction can be accelerated by the reduction of dissolved oxygen which is called depolarization [2]:

$$
4 \mathrm{H}++\mathrm{O} 2+4 \mathrm{e}-\rightarrow 2 \mathrm{H} 2 \mathrm{O}
$$

Dissolved oxygen reacts with hydrogen atoms which are adsorbed randomly on the iron surface, regardless of the presence or absence of impurities in the metal. Oxidation reactions take place as quickly as oxygen reaches the metal surface [2].

\subsection{Cathodic Protection}

Corrosion in the cathodic protection process with sacrificial anode is the reaction of a metal in an electrolyte solution so that the metal becomes anodic due to an oxidation reaction while other metals become cathodic. The anodic and cathodic processes occur simultaneously [1]. Corrosion based on an electrochemical process (electrochemical process) consists of 4 main components [12] as shown in Figure 2, namely: 


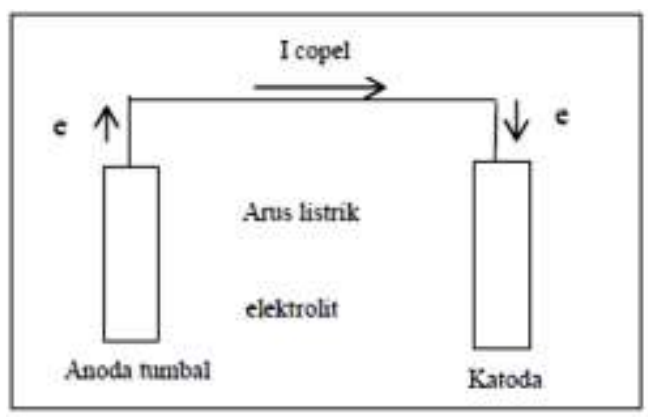

Fig.2 Simple Corrosion Cell (Trethewey, 1991)

- Anode (Anode) is a material that is sacrificed/corroded by releasing electrons from neutral metal atoms to form the ions concerned. These ions may remain in solution or react to form insoluble corrosion products.

- Cathode is a metal that is protected from corrosion.

- An electrolyte is a solution that has the property of conducting electricity. Electrolytes can be acids, bases and salt solutions. Electrolyte solutions have an important role in metal corrosion because these solutions can make electrical contact between the anode and cathode

- Anode and Cathode Relationship. Namely the existence of an electrical connection so that the current in the corrosion cell can flow.

The principle of cathodic protection is to protect the metal as the cathode, which is to conduct an electric current with an electrolyte medium to the metal. The principle of corrosion control with this cathodic protection technique is applied to the protection of the hull under the waterline which is made of steel. In the hull, the corrosion rate is strongly influenced by the sea water flow rate. The process of metal corrosion in seawater solution takes place electrochemically, so that on the surface of the corroded metal, anodic and cathodic areas are formed [1]. For example, for ferrous metal which corrodes in aqueous solution at neutral $\mathrm{pH}$ and is aerated, the cell reaction is as follows:

Anodic:

Fe -------- Fe 2+ + 2e (oxidation)

cathodic

$02+\mathrm{H} 20+2 \mathrm{e}--------2$ 0H- (reduction)

Cell reaction:

$\mathrm{Fe}+02+\mathrm{H} 20$ $\mathrm{Fe} 2++20 \mathrm{H}-$

Electrochemical cell reaction is the transfer of electrons at the metal-electrolyte interface caused by an oxidation-reduction reaction [1]. This method is carried out by flowing direct current through the 
electrolyte to the metal so that the interfacial potential of the metal - electrolyte solution drops to a certain value so that the corrosion rate of the metal can be minimized (according to tolerance).

\subsection{Literature Review}

Corrosion rate is the rate of thinning or destruction of metal surfaces caused by corrosion, and is expressed in the form of a certain value in units of length per unit time [14]. To determine the reliability of a material in controlling corrosion, several studies measure how much the corrosion rate of the material is measured by its weight reduction. In a study conducted by Jasron (2014), to determine the combination of two cathodic protection metals that has the best reliability, it is seen through the corrosion rate. In that study the combination of cathodic protection between steel and aluminum is better than the combination of aluminum with brass and steel with brass because Aluminum as anode has the highest corrosion rate.

Table 3. Corrosion rate of combination of cathodic protection materials

\begin{tabular}{lll}
\hline COMBINATION & $\begin{array}{l}\text { LK Material I } \\
(\mathbf{m m} / \mathbf{y r})\end{array}$ & $\begin{array}{l}\text { LK Material II } \\
(\mathbf{m m} / \mathbf{y r})\end{array}$ \\
\hline Steel-Aluminum & $0.009-0.02$ & $0.1-0.005$ \\
\hline Aluminum-Brass & $0.08-0.04$ & $0.02-0.01$ \\
\hline Steel-Brass & $0.1-0.04$ & $0.009-0.01$ \\
\hline
\end{tabular}

Source. Jason, 2014

It can be seen in the table above that the corrosion rate of aluminum is the fastest per year compared to other materials. Based on these data, Aluminum is the best material as a sacrificial anode in cathodic protection systems.

Then Fitri AS, et al. (2014) conducted an experimental study on how cathodic protection with the sacrificial anode method could control the corrosion rate. Experiments using steel as cathode and an alloy of zinc and aluminum as anode with size 3 variations in seawater media, and anode composition according to table 4 below.

Table 4. Chemical composition of zinc alloy and aluminum alloy

\begin{tabular}{ll}
\hline $\begin{array}{l}\text { Zinc Alloy } \\
(\text { C-sentry })^{+}\end{array}$ & Aluminum Alloy (Galvalum) ${ }^{++}$ \\
\hline $\mathrm{Al}: 0.4-0.6$ & $\mathrm{Al}:$ leftovers \\
$\mathrm{Cd}: 0.075-0.125$ & $\mathrm{Cu}:<0.006$ \\
$\mathrm{Cu}:<0.003$ & $\mathrm{Fe}:<0.1$ \\
$\mathrm{Fe}:<0.0014$ & $\mathrm{Hg}: 0.02-0.05$ \\
$\mathrm{~Pb}:<0.15$ & $\mathrm{Si}: 0.11-0.21$ \\
$\mathrm{Si}:<0.125$ & $\mathrm{Zn}: 0.3-0.5$ \\
$\mathrm{Zn}:$ remainder & Others: $<0.02$ \\
\hline
\end{tabular}


The experimental results can be seen in Figure 3 below

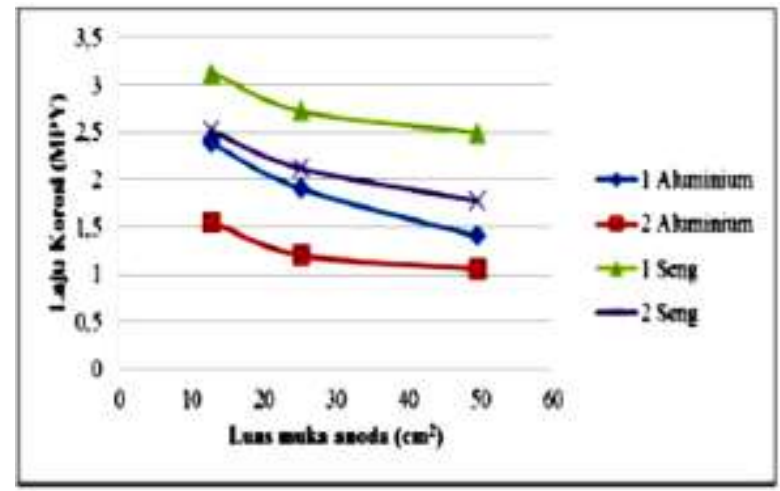

Figure 3. Corrosion Rate of Al and Zn Alloy Anodes

Source. Fitri et al, 2014

In the picture above, it can be explained that the highest corrosion rate is experienced by aluminum alloys, this can be interpreted that number 1 aluminum alloy is a better anode in protecting steel as a cathode, for more details can be seen in table 5 below.

Table 5. Percentage of Corrosion Rate of Steel with Sacrificial Anode Variations

\begin{tabular}{|c|c|c|c|c|}
\hline Face Size & \multicolumn{4}{|c|}{ Steel Corrosion Rate (\%) } \\
\hline $\begin{array}{l}\text { Anode } \\
\left(\mathrm{cm}^{2}\right)\end{array}$ & $\begin{array}{c}1 \\
\text { aluminum }\end{array}$ & $\begin{array}{c}2 \\
\text { aluminum }\end{array}$ & $\begin{array}{c}1 \\
\text { Zinc }\end{array}$ & $\begin{array}{c}2 \\
\text { Zinc }\end{array}$ \\
\hline 12.8 & 0.52 & 0.69 & 0.38 & 0.48 \\
\hline 25,12 & 0.62 & 0.77 & 0.46 & 0.55 \\
\hline 49.6 & 0.72 & 0.8 & 0.5 & 0.6 \\
\hline
\end{tabular}

From the table above, it can be seen that aluminum alloys have a higher percentage of corrosion rate than zinc alloys, namely $80 \% \mathrm{Al}$ and $60 \% \mathrm{Zn}$ (the highest value), the larger the anode surface area, the higher the percentage of corrosion rate. This means that the protection of steel against corrosion by sacrificial anode is better using aluminum. This is because the potential of steel is more positive than aluminum. In addition, the wider the surface area of the sacrificial anode, the better the protection against steel will be.

Furthermore, Isni Utami, (2009) conducted a study on controlling the corrosion rate using the cathodic protection method with a sacrificial anode in an aqueous environment. The experimental material used AISI-SAE 1018 steel and aluminum and zinc sacrificial anodes. The environment does not use sea 
water like the research above, but uses a 3.5\% NaCl solution. Experiments were carried out according to time variations. The experimental results can be seen in the table below, as follows:

\section{Table 5. Corrosion rate of steel with $\mathrm{Al}$ and $\mathrm{Zn}$ anodes in $3.5 \% \mathrm{NaCl}$ environment}

\begin{tabular}{|l|c|l|c|}
\hline \multicolumn{2}{|c|}{ Aluminum (Al) Anode } & \multicolumn{2}{|c|}{ Zinc $(\mathrm{Zn})$ Anode } \\
\hline $\begin{array}{l}\text { Time } \\
(\text { O'clock })\end{array}$ & $\begin{array}{l}\text { Steel } \\
\text { Corrosion Rate } \\
(\mathrm{mpy})\end{array}$ & $\begin{array}{l}\text { Time } \\
\text { (O'clock) }\end{array}$ & $\begin{array}{l}\text { Steel } \\
\text { Corrosion Rate } \\
(\mathrm{mpy})\end{array}$ \\
\hline 168 & 1.6201 & 168 & 2.7128 \\
\hline 336 & 1.7915 & 336 & 4.8507 \\
\hline 504 & 1.6413 & 504 & 4.3149 \\
\hline 672 & 1.5470 & 672 & 4.5232 \\
\hline 840 & 1.6816 & 840 & 4.7552 \\
\hline
\end{tabular}

Source. Isni Utami, 2009

Corrosion rate is the rate of thinning or destruction of metal surfaces caused by corrosion. In the table above, the corrosion rate of steel with aluminum anode has a lower corrosion rate than zinc, this means that the rate of surface damage of steel with aluminum anode is slower when using a zinc anode. Based on the weight of the experimental steel using anode and without anode in $3.5 \% \mathrm{NaCl}$ solution, $\mathrm{Al}$ anode was able to reduce the corrosion rate of steel by an average of $82 \%$ and metal $\mathrm{Zn} 50 \%$.

Herald (2018) analyzed the effect of Aluminum (Al) composition on the microstructure, hardness and corrosion rate of Zinc (Zn)-based Sacrificial Anodes for ships using the casting method. The research method was carried out experimentally, namely the manufacture of sacrificial anode material through casting, the material used was Zinc ( $>99 \%)$ in the form of ingots, then added aluminum alloy (>99\%) and etching materials such as $40 \mathrm{gr} \mathrm{CrO} 3,3 \mathrm{gr} \mathrm{Na} 2 \mathrm{SO} 4$ and $200 \mathrm{ml}$ of water. . The sacrificial anode alloy was made in 4 variations according to the aluminum content, namely $0 \%, 0.2 \%, 0.4 \%$ and $0.6 \%$. Then the results of this study carried out four tests. Composition testing with OES, metallographic testing to see the microstructure. Hardness test to determine the value of hardness. XRD test to determine the formed phase. After the casting experiment and the sacrificial anode material testing were completed, the Tafel test was carried out to determine the corrosion rate.

During the smelting process, aluminum undergoes oxidation because it easily reacts with oxygen, this causes an increase in the percentage of aluminum composition. Then the results of the hardness test for the sacrificial anode alloy, along with the increase in the percentage of aluminum, the hardness also increases, namely: Metal Zinc $(\mathrm{Zn}) 0 \%=50.53 \mathrm{HB}, \mathrm{Zn}-0.2 \mathrm{Al}=51.83 \mathrm{HB}, \mathrm{Zn}-0.4 \mathrm{Al}=55.46 \mathrm{HB}$ and $\mathrm{Zn}-0,6 \mathrm{Al}=59.26 \mathrm{HB}$. Later alloy sacrificial anodes experimental results of this study conducted Tafel test (ASTM standard G5 and ASTM G102) to determine the rate of corrosion and the potential level cell ( o E) as per Table 6 below. 
Table 6. The results of the corrosion rate and potential for sacrificial anode alloys using the Tafel. Test

\begin{tabular}{|c|c|c|c|}
\hline Zn Alloy & Ecorr (Volts) & Icor $\left(\mathrm{A} / \mathrm{cm}^{2}\right)$ & $\begin{array}{c}\text { Corrosion } \\
\text { Rate(mm/year) }\end{array}$ \\
\hline Zn $100 \%$ & -1.1224 & $2,4356.10^{-5}$ & 0.82544 \\
\hline $\mathrm{Zn}-0.2 \% \mathrm{Al}$ & -1.0994 & $3,6137.10^{-5}$ & 1.2247 \\
\hline $\mathrm{Zn}-0.4 \% \mathrm{Al}$ & -1.1258 & $3,9581.10^{-5}$ & 1.3414 \\
\hline $\mathrm{Zn}-0.6 \% \mathrm{Al}$ & -1.1254 & $4,8106.10^{-5}$ & 1.6303 \\
\hline \multicolumn{4}{|c}{ Source. Herald, 2018} \\
\hline
\end{tabular}

In the table above, it can be seen that the addition of the percentage of aluminum in the sacrificial anode alloy greatly affects the corrosion rate, the greater the aluminum content, the greater the corrosion rate. This means that the influence of aluminum on the anode alloy's ability to resist corrosion is very large. For more details, the effect of aluminum on the corrosion rate can be seen in the image below.

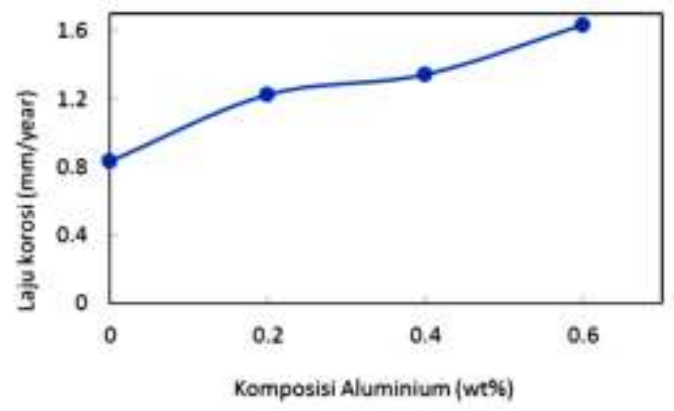

Figure 4. Corrosion Rate of Zn-Al. Alloy Source. Herald, 2018

For the alloy potential in each composition has an average value where this potential will greatly affect the cathodic protection process.

\subsection{Discussion}

As previously explained, cathodic protection is one of the most widely used corrosion control methods for ship hulls below the waterline. Corrosion protection on the hull below the waterline mostly uses a combination of coatings such as paint and cathodic protection. To optimize corrosion control on ships in the marine environment, it is necessary to apply an appropriate cathodic protection system. According to the standard of the National Association of Corrosion Engineers (NACE) RP-0169 in Kim, et all. 2016, the criteria for cathodic protection at room temperature, for a negative potential (cathodic) of at least $770 \mathrm{mV}(0.77 \mathrm{~V})$ and the corrosion rate must be lower than $0.0254 \mathrm{~mm} / \mathrm{y}$ when cathodic protection is active [15]. 
Shreir, 1994 in Isni Utami, 2011 mentions the greater the corrosion rate, the greater the protective current density required to fulfill cathodic protection. The corrosion rate of steel on ships, of course, is greatly influenced by the flow of sea water. In the literature review that was submitted previously, the discussion was carried out in conditions of sea water with no flow or stationary fluid. H.H. Uhlig, 1985 and John Morgan, 1987 support by stating that the corrosion rate of steel in a seawater environment will increase parabolically with an increase in the relative speed of the ship.

Criteria for cathodic protection can change due to one of the dynamics that occur in the seawater environment such as flow velocity [15]. The effect of flow velocity can lead to the formation of calcium carbonate $(\mathrm{CaCO} 3)$ and magnesium hydroxide $(\mathrm{Mg}[\mathrm{OH}] 2)$ which are calcareous deposits and can affect the design of cathodic protection [15]. The rate of formation of calcareous deposits increases with increasing flow velocity due to an increase in the rate of $\mathrm{OH}$ formation on the metal surface [15]. This is also supported by YP Asmara, (2007) who said that in his experiment the greater the cathodic protection potential, the greater the current decrease, this was due to the formation of salt deposits resulting from the reaction between calcium elements present in seawater due to alkaline conditions produced by cathodic protection system. based on the SEM (secondary electron microscope) test, it is known that the majority of the constituent elements of the deposit are magnesium and calcium [16]. When analyzed more deeply, it was found that in the area around the deposit there had been corrosion pitting. This is confirmed by anodic polarization scan which shows a decrease in pitting corrosion potential of $200 \mathrm{mV}$.

Based on the above discussion, in designing cathodic protection, the selection of sacrificial anodes with consideration of the performance of the anodes needs to be done in order to anticipate the effects that arise that cause the performance of cathodic protection to be not optimal. Anggono (2000) in Eko JS (2010) states that the basis for selecting the sacrificial anode should be based on performance considerations which include; density, protection potential, thrust stress, capacity and efficiency. For this reason, the criteria for sacrificial anodes according to the 2006 BKI can be seen in the table below.

Table 7. Criteria for selecting sacrificial anodes

\begin{tabular}{llcc}
\hline No & \multicolumn{1}{c}{ Criteria } & Zn Alloy & Al Alloy \\
\hline $\mathbf{1}$ & Density $\left(\mathrm{Kg} / \mathrm{dm}^{3}\right)$ & 7.50 & 2.70 \\
\hline $\mathbf{2}$ & Potential, (-V), CSE & 1.05 & 1.10 \\
\hline $\mathbf{3}$ & Thrust stress & 0.25 & 0.25 \\
\hline $\mathbf{4}$ & Capacity (Ah/Kg) & 780 & 2700 \\
\hline $\mathbf{5}$ & Efficiency (\%) & 95 & $50-95$ \\
\hline
\end{tabular}

Source. Eko JS (2010) 
Based on the table above, the aluminum sacrificial anode has a better current capacity and lighter density than the zinc alloy sacrificial anode. Trethewey, 1991 in Fitri LS (2017) mentions that the protection that will be provided by zinc will be very good if the metal is dissolved at a constant rate. When corroded in seawater, pure zinc will form a layer that makes it impermeable to water so that the outflow is limited. The impurity that has the most damaging effect on the anode is iron. Its solubility in zinc is very low below $0.0014 \%$ so that if it is in excess, the excess will be in the form of separate particles. This will form a local galvanic cell in the form of a layer of zinc hydroxide/zinc carbonate which is insoluble and does not conduct electricity, so the anode is not effective. Meanwhile, aluminum in this condition will form pitting corrosion in seawater due to the presence of a cathodic oxide layer when in free air. Therefore, it is necessary to have additional alloys to anticipate these alloys. It is for this purpose that aluminum alloys have been developed using zinc and mercury or zinc and indium. Aluminum alloys have a higher electrical power/weight ratio than zinc alloys and the use of aluminum alloys has begun to replace the use of zinc in several applications, especially in the offshore industry (Trethewey, 1991). The following is the recommended sacrificial anode on ships based on the Indonesian Classification Bureau in 2004 in the Regulation for the Corrosion Protection and Coating System.

Table.2.5. Aluminum sacrificial anode application in seawater

\begin{tabular}{|c|c|c|c|}
\hline ELEMENT & KI-Al1 & KI-Al2 & KI-Al3 \\
\hline $\mathbf{S i}$ & 0.10 & 0.10 & $\mathrm{~S} 1+\mathrm{Fe}$ \\
\hline $\mathbf{F e}$ & 0.10 & 0.13 & 0.10 \\
\hline $\mathrm{Cu}$ & 0.005 & 0.005 & 0.02 \\
\hline $\mathbf{M N}$ & N/A & N/A & $0.15-0.50$ \\
\hline Zn & $2.0-6.0$ & $4.0-6.0$ & $2.0-5.0$ \\
\hline $\mathbf{T i}$ & - & - & $0.01-0.05$ \\
\hline in & $0.01-0.03$ & - & $0.01-0.05$ \\
\hline Sn & - & $0.05-0.15$ & - \\
\hline Other & 0.10 & 0.10 & 0.10 \\
\hline Al & Residue & Residue & Residue \\
\hline $\begin{array}{l}\text { Potential } \\
\left(\mathbf{T}=\mathbf{2 0}^{\circ} \mathrm{C}\right)\end{array}$ & $\begin{array}{c}-1.05 \mathrm{~V} \\
\mathrm{Ag} / \mathrm{AgCl} / \mathrm{See}\end{array}$ & $\begin{array}{c}-1.05 \mathrm{~V} \\
\mathrm{Ag} / \mathrm{AgCl} / \mathrm{See}\end{array}$ & $\begin{array}{c}-1.05 \mathrm{~V} \\
\mathrm{Ag} / \mathrm{AgCl} / \mathrm{See}\end{array}$ \\
\hline
\end{tabular}


Vol. 4, Issue.6, Nov-Dec 2021, p no. 295-311

\begin{tabular}{cccc}
$\mathbf{Q g}\left(\mathbf{T}=\mathbf{2 0}{ }^{\circ} \mathbf{C}\right)$ & $2000 \mathrm{Ah} / \mathrm{kg}$ & $2000 \mathrm{Ah} / \mathrm{kg}$ & $2700 \mathrm{Ah} / \mathrm{kg}$ \\
\hline $\mathbf{E f f i c i e n c y}$ & $95 \%$ & $95 \%$ & $95 \%$ \\
$\left(\mathbf{T}=\mathbf{2 0}{ }^{\circ} \mathbf{C}\right)$ & & & \\
\hline
\end{tabular}

Table.2.6. Sacrificial anode Zinc application in seawater media

\begin{tabular}{ccc}
\hline Element & KI-Zn1 & KI-Zn2 \\
\hline $\mathbf{A l}$ & $0.100-0.500$ & 0.1000 \\
\hline $\mathbf{C D}$ & $0.025-0.070$ & 0.0040 \\
\hline $\mathbf{C u}$ & 0.0050 & 0.0050 \\
\hline $\mathbf{F e}$ & 0.0050 & 0.0014 \\
\hline $\mathbf{P b}$ & 0.0060 & 0.0060 \\
\hline $\mathbf{Z n}$ & $>99.22$ & 99,880 \\
\hline Potential $\left(\mathbf{T}=\mathbf{2 0}{ }^{\circ} \mathbf{C}\right)$ & $-1.03 \mathrm{~V}, \mathrm{Ag} / \mathrm{AgCl} / \mathrm{See}$ & $-1.03 \mathrm{~V}, \mathrm{Ag} / \mathrm{AgCl} / \mathrm{See}$ \\
\hline $\mathbf{Q g}\left(\mathbf{T}=\mathbf{2 0}{ }^{\circ} \mathbf{C}\right)$ & $780 \mathrm{Ah} / \mathrm{kg}$ & $780 \mathrm{Ah} / \mathrm{kg}$ \\
\hline Efficiency $\left.\mathbf{( T = 2 0}{ }^{\circ} \mathbf{C}\right)$ & $95 \%$ & $95 \%$ \\
\hline
\end{tabular}

In optimizing the hull protection material, in addition to considering the anode performance as described above, the position of the anode also affects the corrosion rate. The laying of the sacrificial anode position also has an influence in restraining the flow of sea water. Several studies have shown that laying the sacrificial anode vertically or horizontally affects the corrosion rate of the sacrificial anode. According to Eko Julianto (2010), the aluminum alloy sacrificial anode mounted on the hull plate vertically can slow down the average corrosion rate of $0.304 \mathrm{~mm} /$ year after the ship has sailed for 3 years. Then, the aluminum alloy sacrificial anode mounted on the hull plate longitudinally, can slow down the corrosion rate by an average of $0.327 \mathrm{~mm} / \mathrm{year}$, after the ship has sailed for 3 years. Furthermore, L. Pongsapan and A. Suhadi (2010) in their research results found that the corrosion rate on steel plates protected by the zinc alloy sacrificial anode of product A was $0.0626 \mathrm{~mm} / \mathrm{year}$ while the vertical protection was $0.0689 \mathrm{~mm} / \mathrm{year}$. The corrosion rate on the steel plate protected by the zinc alloy sacrificial anode of product B is $0.0867 \mathrm{~mm} / \mathrm{year}$ while the vertical protection is $0.0890 \mathrm{~mm} / \mathrm{year}$. Where the sacrificial anode of zinc alloy product $\mathrm{A}$ with $\mathrm{Zn}$ composition $=99.80 \%$ and zinc alloy sacrificial anode of product B with Zn composition $=99.20 \%$. 
Vol. 4, Issue.6, Nov-Dec 2021, p no. 295-311

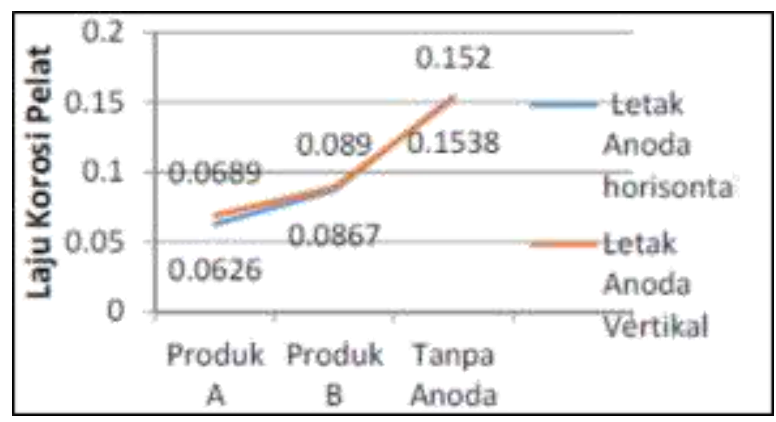

Figure 5. Comparison of Corrosion Rates of Zinc Alloy Sacrificial Anodes Horizontal and Vertical Positions

Source. L. Pongsapan and A. Suhadi (2010)

In the graph above, it can be seen that in a horizontal position, the corrosion rate is slower than placing the anode in a vertical position.

\section{CONCLUSION}

a. Aluminum alloy has the best ability as a sacrificial anode

b. The corrosion rate of steel in a seawater environment will increase parabolically with increasing ship speed. The effect of flow velocity can lead to the formation of calcium carbonate $(\mathrm{CaCO} 3)$ and magnesium hydroxide $(\mathrm{Mg}[\mathrm{OH}] 2)$ which are calcareous deposits that affect the design of cathodic protection.

c. The selection of the sacrificial anode is based on performance considerations, namely; density, protection potential, thrust stress, capacity and resulting efficiency

d. Optimization of the protective material for the hull, it is necessary to consider the position of the anode. The placement of the anode in a vertical or horizontal position has an influence on the speed of the corrosion rate where the vertical position has a slower corrosion rate than the horizontal position.

\section{REFERENCES}

[1] I. Utami, "Proteksi Katodik Dengan Anoda Tumbal Sebagai Pengendali Laju Korosi Baja Dalam Lingkungan Aqueous," J. Tek. Kim., vol. 3, no. 2, pp. 240-245, 2009.

[2] P. R. Roberge, Handbook of Corrosion Engineering, vol. 98, no. 10. New York: McGrawHill, 2000.

[3] F. Afriani, Komalasari, and Zultiniar, "Proteksi Katodik Metoda Anoda Tumbal Untuk Mengendalikan Laju Korosi,” Jom FTEKNIK, vol. 1, no. 2, pp. 1-12, 2014.

[4] B. Sudjasta, P. J. Suranto, and H. Setiani, “Analisis Kebutuhan Pemasangan Zink Anode 
Untuk Mencegah Korosi Pada Lambung Kapal Kapal General Cargo,” Bina Tek., vol. 14, no. 2, p. 209, 2018, doi: 10.54378/bt.v14i2.402.

[5] Sugiyono, Metode Penelitian Kuantitatif, Kualitatif dan $R \&$ D, Ke-19. Bandung: CV. Alfabeta, 2013.

[6] Hardani et al., Metode Penelitian Kualitatif \& Kuantitatif, Ke-1. Yogyakarta: CV. Pustaka Ilmu Group Yogyakarta, 2020.

[7] A. W. Kurniawan and Z. Puspitaningtyas, Metode Penelitian Kuantitatif, Ke-1., vol. 4, no. 4. Yogyakarta: Pandiva Buku, 2016.

[8] S. Setiawan, "Studi Kepustakaan adalah: Tujuan, Sumber, Metode dan Jenis," gurupendidikan, Sep. 10, 2020. https://www.gurupendidikan.co.id/studi-kepustakaan/\#ftocheading-1 (accessed Jan. 26, 2021).

[9] M. Sari, "Penelitian Kepustakaan (Library Research) dalam Penelitian Pendidikan IPA," Nat. Sci. J. Penelit. Bid. IPA dan Pendidik. IPA, vol. 6, no. 1, pp. 41-53, 2020, [Online]. Available: https://ejournal.uinib.ac.id/jurnal/index.php/naturalscience/article/view/1555/1159.

[10] A. Leonardo, C. Oktavia, H. Ardikatama, M. I. Hidayat, M. P. Trihastoro, and R. A. Putra, “Jurnal Konsep Pengukuran dan Esensi Analisis Web,” Jul. 04, 2020.

https://iamryanap.wordpress.com/2020/07/04/jurnal-konsep-pengukuran-dan-esensi-analisisweb/ (accessed Apr. 12, 2021).

[11] P. R. Roberge, Corrosion Engineering - Principles and Practices, vol. ChE9, no. 2. New York: The McGraw-Hill Companies, Inc, 2008.

[12] M. F. Sidiq, “Analisa Korosi dan Pengendaliannya,” vol. 3, no. 1, pp. 25-30, 2013.

[13] I. Utami, "Model Rotating Cylinder Elektrode Untuk Menentukan Keperluan Rapat Arus Proteksi Katodik,” J. Teknol. TECHNOSCIENTIA, vol. 1, no. 1, pp. 58-66, 2008.

[14] J. U. Jasron, “Analisa Laju Korosi Logam tak Sejenis pada Berbagai Jenis Logam,” LONTAR J. Tek. Mesin Undana, vol. 01, pp. 26-33, 2014.

[15] J. H. Kim, Y. S. Kim, and J. G. Kim, "Cathodic protection criteria of ship hull steel under flow condition in seawater," Ocean Eng., vol. 115, no. March 2016, pp. 149-158, 2016, doi: 10.1016/j.oceaneng.2016.02.024.

[16] Y. P. Asmara, "Karakteristik Arus Dan Potensial Katodik Pada Perlindungan Sistem Arus Terpasang Terhadap Stainless Steel Type 304 di Lingkungan Air Laut," J. Kim., vol. 1, pp. 21-28, 2007. 


\section{International Journal of Education and Social Science Research}

[17] I. Utami, "Model Pengendalian Katodik Dalam Elektrode Disk Pemutar Sistem Korosi," Jurnal

Teknik Industri, Vol. 12, No. 1, Februari 2011: 65-70. 